\title{
Psychometric Properties of the Spanish Human System Audit Short-Scale of Transformational Leadership
}

\author{
Rita Berger, Marina Romeo, Joan Guardia, Montserrat Yepes, and Miguel Angel Soria \\ Universidad de Barcelona (Spain)
}

\begin{abstract}
The aim of this research is to examine the psychometric properties of a Spanish version of the Human System Audit transformational leadership short-scale (HSA-TFL-ES). It is based on the concept of Bass developed in 1985. The HSA-TFL is a part of the wider Human System Audit frame. We analyzed the HSA-TFL-ES in five different samples with a total number of 1,718 workers at five sectors.

Exploratory Factor Analysis corroborated a single factor in all samples that accounted for $66 \%$ to $73 \%$ of variance. The internal consistency in all samples was good $(\alpha=.92-.95)$. Evidence was found for the convergent validity of the HSA-TFL-ES and the Multifactor Leadership Questionnaire. These results suggested that the HSA-TFL short-scale is a psychometrically sound measure of this construct and can be used for a combined and first overall measurement. Keywords: transformational leadership, Multifactorial Leadership Questionnaire, Human Systems Audit, exploratory factor analysis.
\end{abstract}

El objetivo de esta investigación es examinar las propiedades psicométricas de la versión española de la escala corta de Liderazgo Transformacional de la Auditoría del Sistema Humano (HSA-TFL-ES). La escala se basa en el concepto de Liderazgo Transformacional desarrollado por Bass en 1985. La HSA-TFL-ES ha sido administrada a un total de 1,718 trabajadores, distribuidos en cinco muestras diferentes correspondientes a distintos sectores empresariales. El análisis factorial exploratorio corroboró la existencia de un solo factor que explica entre $66 \%$ y $73 \%$ de la varianza. La consistencia interna obtenida ha sido buena $(\alpha=.92-.95)$. Además, los resultados obtenidos muestran validez convergente entre la escala HSA-TFL-ES y el Cuestionario Multifactorial de Liderazgo (Multifactorial Leadership Questionnaire - MLQ). Los resultados evidencian que la escala corta HSA es una medida psicométricamente adecuada del constructo de Liderazgo Transformacional, por lo que puede ser utilizada para una primera medición global del mismo.

Palabras clave: liderazgo transformacional, Multifactorial Leadership Questionnaire, Auditoría del Sistema Humano, análisis factorial exploratorio.

Correspondence concerning this article should be addressed to Rita Berger. Department of Social Psychology, Facultad de Psicología, Universidad de Barcelona. Passeig de la Vall d'Hebron, 171, 08035 Barcelona (Spain). Phone: +34 933125193. Fax: +34 934021366. E-mail: ritaberger@ub.edu 
The aim of this study is to explore the psychometric properties of a Spanish Transformational Leadership Shortscale. Transformational leadership has been studied in a large number of investigations developed over the last 25 years. This shows the interest of scholars in the concept (Hunt, 1999). Bennis (2007) in the introduction to a special issue on leadership in the American Psychologist, points out that transformational leadership can be considered exemplary leadership, because it is essential for solving current problems arising from threats to world stability. Despite the recognised importance of transformational leadership, empirical studies show a certain level of disagreement on the factor structure (Carless, 1998; Lowe, Kroeck, \& Sivasubramaniam, 1996; Tejeda, Scandura, \& Pillai, 2001; Tepper \& Percy, 1994; Tracey \& Hinkin, 1998), as proposed by Bass (1985). A fundamental point concerns whether Bass's transformational leadership should be represented specific factors or a general one represented by specific factor or by a general one. The concept of transformational leadership, as developed by Bass (1985), has four dimensions, the so-called "Four I's": Inspirational motivation (IM) means that the leader is able to create a common vision. This includes a charismatic appearance and the ability to articulate the vision. Individualized consideration (IC) is the enablement to develop individual strengths. A transformational leader refers to each follower as an individual who has his own very personal longings and abilities. Intellectual stimulation (IS) refers to the extent to which a leader motivates his followers to find solutions for intellectual ideas and to find new ways of analyzing and solving a problem. Lastly, Idealized influence (II) includes the emphasis on norms and values. In order to be truly transformational, a leader has to reflect certain moral values (Bass, 1985).

Despite the numerous studies dedicated to examining the dimensionality of transformational leadership, there does not seem to be evidence of one predominant factor structure consistently emerging from these studies (Den Hartog, Van Muijen, \& Koopman, 1997). Apart from the results of these empirical studies regarding the dimensionality of Bass transformational leadership concept, theoretical arguments against the proposed factor structure of transformational leadership also exist. Some authors have argued conceptually for a different set of factors to those proposed by Bass. Also, it has become increasingly difficult to make a theoretical distinction between the subdimensions of inspirational motivation and charisma (Barbuto, 1997; Rafferty \& Griffin, 2004).

Varieties of transformational leadership instruments are available, each one assessing perceived core components, and containing different kinds of behavioural practices (Alimo-Metcalfe \& Alban-Metcalfe, 2005; Carless, Wearing, \& Mann, 2000; Conger \& Kanungo, 1994; Rafferty \& Griffin, 2004). One of the most well known questionnaires on transformational leadership is the Multifactorial Leadership
Questionnaire (MLQ) proposed by Bass (1985) and Bass and Avolio (1997), recognized internationally as a valid measure of leadership and translated into many languages. Several meta-analyses provided evidence for the criterionrelated validity of transformational leadership as measured by the MLQ (Dumdum, Lowe, \& Avolio, 2002; Fuller, Patterson, Hester, \& Stringer, 1996; Judge \& Piccolo, 2004), which consistently showed a positive impact on both subjective (Lowe, Kroeck, \& Sivasubramaniam, 1996) and objective (Barling, Weber, \& Kelloway, 1996; Geyer \& Steyrer, 1998) performance criteria. Transformational leadership behavior has been empirically linked to increased employee satisfaction (e.g., Podsakoff, MacKenzie, Moorman, \& Fetter, 1990) and job satisfaction (Nemanicha \& Keller, 2007), organizational commitment (e.g. Bycio, Hackett, \& Allen, 1995), to acquisition acceptance, supervisor-rated performance, extra effort (e.g. Seltzer \& Bass, 1990), turnover intention (e.g. Bycio, Hackett, \& Allen, 1995), organizational citizenship (e.g. Podsakoff, MacKenzie, Paine, \& Bachrach, 2000), overall employee performance (e.g. Yammarino, Spangler, \& Bass, 1993), organizational (Bass \& Avolio, 1994), unit performance (Bass, Avolio, Jung, \& Berson, 2003) and to organizational effectiveness (Lowe et al., 1996). It also predicts positive innovation (Aragón-Correa, GarcíaMorales, \& Cordón-Pozo, 2007; Jung, Chow, \& Wu, 2003).

The importance of measuring transformational leadership in wider practical contexts seems obvious. The increased dynamic, uncertainty and short life cycle of enterprises, also produces the need for short-term and repeated assessment that allows a quick first impression and valid overview that makes it possible to get a deeper, detailed and valid insight into the topic, if necessary (Gibbons, 1992; Hunt, 1991; Quijano, Navarro, Yepes, Berger, \& Romeo, 2008; Shamir, House, \& Arthur, 1993; Yukl, 1998). From this point of view we developed and validated a screening leadership instrument as part of a broader framework, with combined application for assessment in a wider practical organizational context.

This is in line with the aim of the European Foundation for Quality Management (EFQM) (EFQM, 2000). It is dedicated to the development of organizational excellence and identifies leadership as one of its main concerns. Nowadays scientists (Berger, Yepes, \& Quijano, 2007; Howell, Neufeld, \& Avolio, 2005; Quijano et al., 2007) are working on the applicability of leadership concepts to organizational life (e.g. House, Hanges, Javidan, Dorfman, \& Gupta, 2004; Masi \& Cooke, 2000; Molero, Cuadrado, Navas, \& Morales, 2007). This is also supported by the scientist-practitioner-model, developed by the European Network of Organisational Psychology (ENOP) (ENOP, 1998). Finally, the interest in developing short scales has been growing in the area of leadership as well as in other fields (Muck, Hell, \& Gosling, 2007). Those instruments should preferably be quick to apply (and therefore short) (e.g. Carless et al., 2000), based on extensive scientific 
research (Felfe, 2006) and clear in their formulation (Podsakoff, MacKenzie, \& Lee, 2003). As Muck et al. (2007) point out those practical reasons can be considered to outweigh the psychometrical advantages of a larger scale. Although the MLQ is recognized internationally as a valid measure of leadership and has been translated into many languages, its most recent version, the 5X (Bass \& Avolio, 1997) consists of 45 items with 20 items asking about transformational leadership which makes it difficult to use in wider, combined practical circumstances (Quijano, 2006; Quijano et al., 2007) and as a first overall measure of transformational leadership.

The purpose of this work is to analyze, in the frame of the first exploratory stage of a wider research HSA-project, the psychometric properties and to validate the Spanish version of the Human System Audit Transformational Leadership (HSA-TFL-ES) Short-scale for its subsequent use as screening in organizations. The short HSA-TFL is part of a broader integrated framework that aims to diagnose, intervene and improve quality of the human system in the organization (Quijano, Berger, \& Yepes, 2005). It has been developed with newly formulated items first in Spanish, followed by the translation to the English, Portuguese, Polish and German language versions. The Spanish version (HSA-TFL-ES) hereby is the first one developed by the HSA team.

\section{Method}

\section{Participants}

This study is based on five samples (E1 to E5), described in Table 1.The samples consisted of companies in different sectors (automobile, assurance, health care) with more than 250 employees, and all of them established in Spain. Confidentiality agreements with organizations for the samples E1 to E4 with a total number of 1,613 workers refused to provide us with their data segmentation.

The samples E1 to E5 were used for exploring the factor structure of the scale and its internal consistency. The sample E5 was used to analyze the convergent validity of the HSA-TFL-ES Short-scale and consisted of 105 workers from a public hospital in Spain, (21 males, 84 females), aged between 22 and 64 years $(M=39, S D=11.7)$. The public healthcare sector setting was chosen consistent with previous studies of the HSA framework. Participants' occupations were distributed as follows: nurses (48\%), other university degree holders (14\%), nursing assistants (27\%) and technicians $(7 \%)$ with the remaining $4 \%$ not falling under any of the previous categories. Most of them (60\%) were educated to university level, $32 \%$ had attended secondary school and only a minority (5\%) had stopped studying after primary school. Only $5 \%$ of all respondents identified themselves as supervisors. The majority of respondents $(70 \%)$ worked rotatory shifts, and of the remaining $30 \%$ who worked fixed shifts, $27 \%$ worked in the mornings. On average, participants had been working at the hospital for 14 years $(S D=12)$ and more specifically in their departments for 10 years $(S D=10)$ with their mean team size being 36 individuals $(S D=32.6)$. They described their relationship with their supervisors as relatively good $(M=3.63$, range: $0-4, S D=1)$, and relatively close $(M=$ 3.1, range: $0-4, S D=1.2$ ). On average, their perception of others' sharing their opinions about their supervisor was also relatively high $(M=3.7$, range: $0-4, S D=1)$.

\section{Instruments}

The Human System Audit Short-scale for Transformational Leadership in Spanish version (HSA-TFL-ES)

The HSA-TFL Short-scale evaluates the participants' perceptions of their supervisors' transformational leadership in different cultural contexts. The short scale developed by HSA team is based on four theoretical dimensions: inspirational motivation, intellectual stimulation, idealized influence and individual consideration of the concept of transformational leadership as proposed by Bass (1985) with newly formulated items. Native speakers who were experts in the field of organizational psychology translated the scale into Portuguese, English, Polish and German, the Spanish version being the first one developed by the HSA team. For the other versions there is not yet sufficient information on validity and reliability available.

The construction process of the Spanish scale described in this study has passed through different stages. In the first stage the scale was applied to different sectors, exploring its factorial validity and internal consistency using the samples E1 to E5. In the following stage the convergent validity was analysed using exclusively the sample E5. The short HSA-TFL-ES (see items in English translation, Appendix) was developed for the Spanish language in a deductive way using principles such as semantic heterogeneity of the new formulated items, content validity, and a high level of explained variance of the items as regards conceptual dimensions. The content validity of the Spanish short-scale was considered adequate. A panel of five expert judges, with comprehensive research and applied experience, selected the items during the scale construction process. The final eight items were selected on the basis that their factorial coefficient would be higher $\left(\lambda_{\mathrm{ij}}>.85\right)$ on the relevant sub-dimension. López-Zafra and Morales (1999) and López-Zafra, De Amicis, and García-Retamero (2005) applied the questionnaire, using an experimental design, to a sample of unemployed workers from automotive and educational sectors in Andalusia (Spain). Their results confirm good internal consistency $(\alpha=.85)$.

The HSA-TFL-ES Short-scale consists of eight items, two of them representing each of the four dimensions. The 
distribution of the eight items to the four theoretical subdimensions is shown in the Appendix. Items were scored on a 5-point Likert-type scale ranging from: $1=I$ strongly disagree to $5=I$ strongly agree.

\section{Multifactor Leadership Questionnaire (MLQ-5X), Spanish version}

In order to test the convergent validity of the HSATFL-ES we used the transformational part of the subordinate version of the Spanish Multifactor Leadership Questionnaire (MLQ-5X), as validated by Molero (1994). Molero's questionnaire was used in sample E5. Items of Molero's (1994) version were scored on a Likert-type scale from 0 $=$ Never to $4=$ Most of the time. For the sake of overall consistency between the HSA-TFL-ES short and the MLQ in this study the scoring of all items was changed from the $0=$ Never to $4=$ Most of the time to a 5-point Likert-type scale ranging from $1=I$ strongly disagree to $5=I$ strongly agree.

This version of the MLQ (MLQ-5X) consists of 45 items. In this study only the transformational part with a total of 20 items was applied.

\section{Procedure}

The questionnaires in all samples were administered over a three-week period with the help of an internal collaborator at the organization after obtaining consent from the organization's committee. After an information session held by a member of the HSA research team, the questionnaires were distributed around different units of the organizations and completed anonymously by volunteers who did not receive any compensation for their participation. The HSATFL-ES questionnaire can be answered in about four minutes. Confidentiality of response is ensured. For the samples E1 to $\mathrm{E} 4$ the response rates are not available for reasons of confidentiality. For sample E5 although 130 questionnaires were distributed, 116 were returned and of these, 9 were discarded due to missing responses. All results using the sample E5 are reported for the remaining 105 respondents.

\section{Data Analysis}

All statistical analyses were conducted using version 16.0 of the Statistical Package for Social Sciences (SPSS). For all the samples E1 to E5, we tested factorial validity and internal consistency of the HSA-TFL-ES Short-scale. Factorial validity was analysed comparing results of exploratory factor analysis for all samples (E1 to E5). Exploratory factor analysis (EFA). The reliability in all samples was examined with Cronbach's alpha.

We assessed the convergent validity of the HSA-TFLES Short-scale by testing, both scales, HSA-TFL-ES Shortscale and the transformational part of the subordinate version of the Spanish Multifactor Leadership Questionnaire (MLQ$5 \mathrm{X}$ ) for any differences between the means of the composite scores of transformational leadership using exclusively the sample E5. Results were compared using the Wilcoxon Signed Ranks test for paired not normally distributed samples.

Table 1

Psychometric Characteristics of the HSA-TFL-ES Short Scale in Different Samples: Number of Factors, Explained Variance, Factor Loadings Range, and Crombach' alpha

\begin{tabular}{|c|c|c|c|c|c|c|}
\hline Samples & $\begin{array}{l}\text { Business sector } \\
\text { /participants }\end{array}$ & $\begin{array}{c}\mathrm{KMO} \text { and Bartlett } \\
\text { sphericity test }\end{array}$ & Factors & $\begin{array}{l}\text { Explained } \\
\text { variance }\end{array}$ & $\begin{array}{c}\text { Factor } \\
\text { loadins range }\end{array}$ & $\alpha$ \\
\hline E1 $(n=102)$ & $\begin{array}{l}\text { Automobile } \\
\text { Managers }\end{array}$ & $\begin{array}{c}.912 \\
530.491 \\
(p<.001)\end{array}$ & 1 & $65.57 \%$ & $.750-.888$ & .924 \\
\hline E2 $(n=407)$ & $\begin{array}{c}\text { Assurance } \\
\text { Whole staff }\end{array}$ & $\begin{array}{c}.94 \\
2,133.076 \\
(p \quad<.001)\end{array}$ & 1 & $66.71 \%$ & $.740-.874$ & .928 \\
\hline E3 $(n=489)$ & $\begin{array}{c}\text { Assurance } \\
\text { Whole staff }\end{array}$ & $\begin{array}{c}.933 \\
2,991.539 \\
(p<.001)\end{array}$ & 1 & $69.61 \%$ & $.724-.884$ & .937 \\
\hline $\mathrm{E} 4(n=615)$ & $\begin{array}{l}\text { Assurance } \\
\text { Whole staff }\end{array}$ & $\begin{array}{c}.935 \\
3,800.503 \\
(p<.001)\end{array}$ & 1 & $69.87 \%$ & $.634-.883$ & .937 \\
\hline $\mathrm{E} 5(n=105)$ & $\begin{array}{l}\text { Health Care } \\
\text { Whole staff }\end{array}$ & $\begin{array}{c}.90 \\
765.93 \\
(p<.001)\end{array}$ & 1 & $73.41 \%$ & $.573-.836$ & .950 \\
\hline
\end{tabular}


Table 2

Item Factor Loadings for the HSA-TFL-ES Short Scale in Different Samples (E1 to E5)

\begin{tabular}{cccccc}
\hline Items & $\begin{array}{c}\text { E1 } \\
(n=102)\end{array}$ & $\begin{array}{c}\text { E2 } \\
(n=407)\end{array}$ & $\begin{array}{c}\text { E3 } \\
(n=489)\end{array}$ & $\begin{array}{c}\text { E4 } \\
(n=615)\end{array}$ \\
\hline 1. & .843 & .854 & .864 & .861 & .875 \\
$(n=105)$
\end{tabular}

Table 3

Inter-Item Correlation Range for the HSA-TF-ES Short Scale in Five Different Samples (E1 to E5 N=1,718)

\begin{tabular}{ccccccc}
\hline Items & 1 & 2 & 3 & 4 & 5 & 6 \\
\hline 2 & $.682-.800$ & & & & & \\
3 & $.593-.641$ & $.664-.763$ & & & & \\
4 & $.526-.735$ & $.503-.692$ & $.427-.740$ & & & \\
5 & $.542-.688$ & $.610-.715$ & $525-.641$ & $.514-.661$ & & $.506-.762$ \\
6 & $.545-.668$ & $.574-.741$ & $.543-.707$ & $.473-.697$ & $.524-.820$ & $.573-.760$ \\
7 & $.635-.836$ & $.581-.751$ & $.501-.694$ & $.451-.746$ & $.535-.757$ & $.603-.725$ \\
8 & $.663-.791$ & $.573-.766$ & $.671-.709$ & $.473-.725$ & $.584-.679$ & .573 \\
\hline
\end{tabular}

Note. All correlations are statistically significant $(p<.003)$.

Results

The level of adequacy of the data for factor analysis was high ( $K M O$ between .90 and .94$)$ in all samples (E1 to E5). Bartlett's Test of Sphericity $\left(\chi^{2}=530.491-2,133.076\right.$, $d f=28, p<.001$ in all samples) indicates an accurate correlation matrix to be analyzed by the factorial model. The extraction process from EFA showed a unidimensional structure in all samples (E1 to E5). Table 1 shows all explained variances, ranging between $65.57 \%$ and $73.14 \%$. The scree-plot also suggested a one-factor solution for each sample (E1 to E5).

As shown in Table 2 in all five samples all items present similar and high factor loadings.

The Cronbach coefficient for the total eight items of the Spanish version of the HSA Transformational Leadership Short-scale ranged in all samples between .92 and .95 .

As shown in Table 3, correlation analysis revealed that in all five samples all items were highly inter-related, with inter-item correlations ranging from .54 to .84 , all statistically significant $(p<.003)$.

Only the sample E5 was used to analyze the convergent validity of the scale. Table 4 presents means and standard deviations for this sample. The means for the items of the HSA-TFL-ES ranged between 1.46 and 2.20. The overall mean for the HSA-TFL-ES was 1.92 for the short scale.
Standard deviation ranged between 1.23 and 1.40. The overall mean for the MLQ was 1.91 .

The Wilcoxon Signed-rank test revealed no significant differences between the average ratings of transformational leadership measured by the MLQ and the HSA Short-scale. The average scores of transformational leadership measured by the MLQ $(M=1.91)$ were almost equal to the average scores of transformational leadership measured by the HSA

Table 4

Item Means (M) and Standard Deviations (SD) for the HSATFL-ES Short Scale and Overall Mean for the Spanish Version of the MLQ (Sample E5 $n=105$ )

\begin{tabular}{ccc}
\hline Items & $M$ & $S D$ \\
\hline 1. & 1.46 & 1.32 \\
2. & 2.11 & 1.35 \\
3. & 2.20 & 1.36 \\
4. & 1.95 & 1.40 \\
5. & 2.12 & 1.25 \\
6. & 1.88 & 1.28 \\
7. & 2.00 & 1.23 \\
8. & 1.58 & 1.32 \\
\hline HSA-TFL & 1.92 & \\
MLQ & 1.91 & \\
\hline
\end{tabular}


Short-scale $(M=1.92)$. Differences are almost non-existent and not significant $(z=-2.84, p=.78)$. The high correlation found between HSA-TFL-ES Short-scale and (MLQ-5X) $(r$ $=.84, p<.001)$ supports convergent validity between these constructs.

\section{Discussion}

The present study examined the psychometric characteristics of the Spanish version of the Human SystemAudit Short-scale for transformational leadership, including its factorial validity, internal consistency and convergent validity. The aim was the development and validation of a screening instrument highlighting the importance of a shorter test for the leadership domain and, as part of a broader framework, its combined application for assessment in a wider practical organizational context. Therefore, the results of five different samples (E1 to E5) concerning factorial validity and reliability were analyzed. Factorial validity of HSA-TFL-ES Short-scale was studied through EFA in five samples (E1 to E5). The concept of transformational leadership in all five samples was found to be unidimensional, in accordance with previous research with the HSA-TFL-ES Short-scale (Berger et al., 2007; Berger, Kolbe, Quijano, Yepes, \& Romeo, 2009) for the concept of transformational leadership.

In this sense, results suggest the possibility of a less differentiated leadership model that contrasts with that of the MLQ, as the most widely used measure of transformational leadership and based on the concept of four factors. In future studies the confirmation of these results by applying confirmatory factor analysis is foreseen.

The value of Cronbach's alpha suggests a high level of internal consistency of the Spanish version of the HSA-TFL Short-scale in all five samples. This implies that the 8-item scale can be used as a reliable measure of transformational leadership.

The Cronbachs' alpha values of the sample E5 are similar to the results of Molero's study (Molero, 2007) where the scoring 1 to 5 was used, as well as when the author used the scoring 0 to 4 (Molero, 1994). The reliability of the scale allows both applications, range from 1 to 5 as well as from 0 to 4 .

The HSA-TFL Short-scale's convergent validity was evaluated by comparing its results with those obtained with the transformational part of the subordinate version of the MLQ-5X (Bass \& Avolio, 1997) in the sample E5. Differences between the mean scores of the construct of transformational leadership using both scales were very slight and statistically non-significant and measured with the same sensitivity. The scales share the same range. The HSA-TFLES Short scale is at the same level as the MLQ, both able to assess transformational leadership. This result shows that the scales can be considered convergent. Additionally, the high correlation found between HSA-TFL-ES Short-scale and (MLQ-5X) also supports convergent validity between these constructs, which inferred that the scales have similar properties and contribute evidence for the overall validity of the scale and a parsimonious questionnaire.

Nevertheless, it is important to note that the present findings do not challenge Bass' proposed structure, since a different instrument to measure transformational leadership with a different purpose for combined and first assessment is used. Viewing the four theoretical sub-dimensions as one factor can be useful in an applied setting, but finer grained issues could still require the differentiation into four conceptually distinct factors.

Various studies have found high inter-correlations between the sub-dimensions of transformational leadership (Avolio, Bass, \& Jung, 1999; Bycio et al., 1995; Carless, 1998; Rowold \& Heinitz, 2007), which supports the unidimensional solution revealed by our data. The unidimensionality of the construct and the high factor loadings obtained for all the items in five different samples implies that the four subdimensions must be present in order for a leader to show transformational leadership. It may be more appropriate to adopt a systemic perspective of leadership that considers it in holisticy. Perhaps by understanding TFL as measured by the HSA as an overarching factor that includes the four transformational leadership behaviours and interaction between their sub-components means that a truly transformational leader has to demonstrate all kinds of the proposed leadership behaviour in the right combination. This has implications for the development of leadership in organizations, where it is a coveted quality.

Concerning the results of the factor loadings of the items in all samples it can be observed that items 2 and 8 present even higher loadings e.g. compared to item 4 . This suggests that items 2 and 8 could be considered as marker items within the scale.

Summing up, the HSA-TFL-ES Short-scale for combined and first assessment presents adequate psychometric properties, so it can be considered a useful instrument for research and more specifically, applied research. This study directly responds to the need, identified by Murphy and Saal (1990), to overcome the distance between scientific research and practice. By this means, the HSA-TFL-ES Short-scale makes systemic approaches towards organizational evaluation and counselling possible. Therefore in the frame of the ongoing research process several studies are foreseen: to confirm the explored factor structure in different samples, to validate the other available language versions, to develop profiles for different sectors and work out sector related norms, to adjust the HSA-TFL for self-ratings in order to be able to add evidence to the instruments' validity using different sources. This scientific validation of an 8-item measure of transformational leadership is undoubtedly a step in the right direction at bridging the gap between science and practice, since it has reached the right point in the trade-off between scientific rigour and practicality that a measure of this sort can offer. 


\section{References}

Alimo-Metcalfe, B., \& Alban-Metcalfe, J. (2005). The crucial role of leadership in meeting the challenges of change. VISIONThe Journal of Business Perspective, 9, 27-39. http://dx.doi. org/10.1177/097226290500900205

Aragón-Correa, J. A., García-Morales, V. J., \& Cordón-Pozo, E. (2007). Leadership and organizational learning's role on innovation and performance: Lessons from Spain. Industrial Marketing Management, 36, 349-359. http://dx.doi.org/10. 1016/j.indmarman.2005.09.006

Avolio, B. J., Bass, B. M., \& Jung, D. I. (1999). Re-examining the components of transformational and transactional leadership using the multifactor leadership questionnaire. Journal of Occupational and Organizational Psychology, 72, 441-462. http://dx.doi.org/10.1348/096317999166789

Barbuto, J. E. (1997). Taking the charisma out of transformational leadership. Journal of Social Behavior and Personality, 12, 689-697.

Barling, J., Weber, T., \& Kelloway, E. K. (1996). Effects of transformational leadership training on attitudinal and financial outcomes: A field experiment. Journal of Applied Psychology, 81, 827-832. http://dx.doi.org/10.1037//00219010.81.6.827

Bass, B. M. (1985). Leadership beyond expectations. New York, NY: Free Press.

Bass, B. M., \& Avolio, B. J. (Eds.) (1994). Improving organizational effectiveness through transformational leadership. Thousand Oaks, CA: Sage Publications.

Bass, B. M., \& Avolio, B. J. (1997). Full range leadership development: manual for the multifactor leadership questionnaire. Palo Alto, CA: Mindgarden.

Bass, B. M., Avolio, B. J., Jung, D. I., \& Berson, Y. (2003). Predicting unit performance by assessing transformational and transactional leadership. Journal of Applied Psychology, 88, 207-218. http://dx.doi.org/10.1037/0021-9010.88.2.207

Bennis, W. J. (2007). The challenges of leadership in the modern world: Introduction to the special issue. American Psychologist, 62, 2-5. http://dx.doi.org/10.1037/0003-066X.62.1.2

Berger, R., Yepes, M., \& Quijano, S. (2007, May). Leadership and management dimensional structure. Paper presented at the $13^{\text {th }}$ European Congress of Work and Organizational Psychology. Stockholm, Sweden.

Berger, R., Kolbe, L., Quijano, S., Yepes, M., \& Romeo, M. (2009, October). Development and analysis of a German version of the HSA Short-scale of Transformational leadership (Human System Audit HSA-TFL). Paper presented at the XIth European Conference on Organizational Psychology and Human Service Work, New challenges and interventions in human services. Coimbra, Portugal.

Bycio, P., Hackett, R. D., \& Allen, J. S. (1995). Further assessments of Bass's (1985) conceptualization of transactional and transformational leadership. Journal of Applied Psychology, 80, 468-478. http://psycnet.apa.org/doi/10.1037/0021-9010.80. 4.468
Carless, S. A. (1998). Assessing the discriminant validity of transformational leader behavior as measured by the MLQ. Journal of Occupational and Organizational Psychology, 7, 353-358. http://dx.doi.org/10.1348/096317901167334

Carless, S. A., Wearing, A. J., \& Mann, L. (2000). A short measure of transformational leadership. Journal of Business and Psychology, 14, 389-405. http://dx.doi.org/10.1023/A:1022 991115523

Conger, J. A., \& Kanungo, R. N. (1994). Charismatic leadership in organizations: Perceived behavioural attitudes and their measurement. Journal of Organizational Behaviour, 15, 439452. http://dx.doi.org/10.1002/1099-1379(200011)21:7<747:: AID-JOB46>3.3. CO;2-A

Den Hartog, D. N., Muijen, J. J., \& Koopman, P. L. (1997). Transactional versus transformational leadership: An analysis of the MLQ. Journal of Occupational and Organizational Psychology, 70, 19-34. http://dx.doi.org/10.1111/j.20448325.1997.tb00628.x

Dumdum, U. R., Lowe, K. B., \& Avolio, B. J. (2002). A metaanalysis of transformational and transactional leadership correlates of effectiveness and satisfaction: An update and extension. In B. J. Avolio \& F. J. Yammarino (Eds.), Transformational and charismatic leadership: the road ahead (pp. 35-66). Amsterdam, The Netherlands: JAI.

European Foundation for Quality Management (2000). Introducing excellence. Retrieved from http://www.efqm.org.

European Network of Organizational Psychologist (1998). European curriculum in W\&O psychology. Reference model and minimal standards. ENOP document de travail, 3. Paris, France: Maison des Sciences de l'Homme.

Felfe, J. (2006). Transformationale und charismatische Führung - Stand der Forschung und aktuelle Entwicklungen [Transformational and charismatic leadership - State of the art and current evolutions]. Zeitschrift für Personalpsychologie 5, 163-176. http://dx.doi.org/10.1026/1617-6391.5.4.163

Fuller, J. B., Patterson, C. E. P., Hester, K., \& Stringer, D. Y. (1996). A quantitative review of research on charismatic leadership. Psychological Reports, 78, 271-287. http://dx.doi. org/10.2466/pr0.1996.78.1.271

Geyer, A. L. J., \& Steyrer, J. M. (1998). Transformational leadership and objective performance in banks. Applied Psychology: An International Review, 47, 397-420. http://dx.doi.org/10.1111/j. 1464-0597.1998.tb00035.x

Gibbons, P. T. (1992). Impacts of organizational evolution on leadership roles and behaviors. Human Relations, 45, 1-13. http://dx.doi.org/10.1177/001872679204500101

House, R. J., Hanges, P. J., Javidan, M., Dorfman, P. W., \& Gupta, V. (2004). Culture, leadership, and organizations: The GLOBE Study of 62 Societies. New York, NY: Sage Publications.

Howell, J. M., Neufeld, B. J., \& Avolio, J. (2005). Examining the relationship of leadership and physical distance with business unit performance. The Leadership Quarterly, 16, 273-285. http://dx.doi.org/10.1016/j.leaqua.2005.01.004

Hunt, J. G. (1991). Leadership: A new synthesis. Newbury Park, CA: Sage. 
Hunt, J. G. (1999). Transformational/charismatic leadership: An historical essay. The Leadership Quarterly, 10, 129-144. http://dx.doi.org/10.1016/S1048-9843(99)00015-6

Judge, T. A., \& Piccolo, R. F. (2004). Transformational and transactional leadership: A meta-analytic test of their relative validity. Journal of Applied Psychology, 89, 755-768. http://dx.doi.org/10.1037/0021-9010.89.5.755

Jung, D. I., Chow, C., \& Wu, A. (2003). The role of transformational leadership in enhancing organizational innovation: Hypotheses and some preliminary findings. The Leadership Quarterly, 14, 525-544. http://dx.doi.org/10. 1016/S1048-9843(03)00050-X

López-Zafra, E., \& Morales, J. F. (1999). Niveles de análisis en el estudio de liderazgo carismático [Levels of analysis in the study of charismatic leadership]. Revista de Psicología Social, 14, 181-198. http://dx.doi.org/10.1174/021347499760259930

López-Zafra, E., De Amicis, C., \& García-Retamero, R. (2005). El Liderazgo transformacional como un proceso grupal: Un análisis desde la perspectiva de género. [Transformational leadership as a group process: An analysis from a gender perspective].Retrieved from http://www.fedap.es/IberPsicologia/ iberpsi10/congreso_lisboa/lopez/lopez.htm

Lowe, K. B., Kroeck, K. G., \& Sivasubramaniam, N. (1996). Effectiveness correlates of transformation and transactional leadership: A meta-analytic review of the MLQ literature. The Leadership Quarterly, 7, 385-425. http://dx.doi.org/10.1016/ S1048-9843(96)90027-2

Masi R. J., \& Cooke R. A. (2000). The effects of transformational leadership on subordinate motivation, empowering norms, and organizational productivity. The International Journal of Organizational Analysis, 8, 16-47. http://dx.doi.org/10.1108/ eb028909

Molero, F. (1994). Carisma y Liderazgo carismático: una aproximación empírica desde las perspectivas de Bass y Friedman [Charisma and Charismatic leadership: An empirical view from the perspectives of Bass and Friedman] (Unpublished doctoral thesis). Universidad Nacional de Educación a Distancia (UNED), Madrid, Spain.

Molero, F., Cuadrado, I, Navas, M., \& Morales, J. F. (2007). Relations and effects of transformational leadership: A comparative analysis with traditional leadership styles. The Spanish Journal of Psychology, 10, 358-368.

Muck, P. M., Hell, B., \& Gosling, S. D. (2007). Construct validation of a short Five- Factor Model Instrument. A selfpeer study on the German adaptation of the Ten-Item Personality Inventory (TIPI-G). European Journal of Psychological Assessment, 3, 166-175. http://dx.doi.org/10. 1027/1015-5759.23.3.166

Murphy, K. R., \& Saal. F. E. (1990). Introduction. In K. R. Murphy \& F. E. Saal (Eds.), Psychology in organizations: Integrating science and practice (pp.1-4). Hillsdale, NJ: Lawrence Erlbaum Associates.

Nemanicha, L. A., \& Keller, R. T. (2007). Transformational leadership in an acquisition: A field study of employees. The
Leadership Quarterly, 18, 49-68. http://dx.doi.org/10.1016/j. leaqua.2008.11.002

Podsakoff, P. M., MacKenzie, S. B., Moorman, R. H., \& Fetter, R. (1990). Transformational leader behaviors and their effects on followers' trust in leader, satisfaction and organizational citizenship behaviours. The Leadership Quarterly, 1, 107142. http://dx.doi.org/10.1016/1048-9843(90)90009-7

Podsakoff, P. M., MacKenzie, S. B., Paine, J. B., \& Bachrach, D. G. (2000). Organizational citizenship behaviors: A critical review of the theoretical and empirical literature and suggestions for future research. Journal of Management, 26, 513-563. http://dx.doi.org/10.1037/a0013079

Podsakoff, P. M., MacKenzie, S. B., \& Lee, J. (2003). Common method biases in behavioral research: A critical review of the literature and recommended remedies. Journal of Applied Psychology, 88, 879-903. http://dx.doi.org/10.1037/00219010.88.5.879

Quijano, S. (Ed.). (2006). Dirección de recursos humanos y consultoría en las organizaciones: El ASH (Auditoría del Sistema Humano). [Human resources management and consultancy in organizations: The HSA (Human System Audit)]. Barcelona, Spain: Icaria.

Quijano, S., Berger, R., \& Yepes, M. (2005). Technical interim project report of the Project Human System Audit for the Health Care Sector (E/04/B/PP-149162). Leonardo da Vinci Program.

Quijano, S., Yepes, M., Berger, R., Romeo, M., Navarro, J., \& Gómez, J. (2007, October). The structure of the construct 'people results' according to the EFQM model in the healthcare sector of certain European countries: a crosscultural study, Paper presented at the $\mathrm{X}^{\text {th }}$ ENOP Conference. Kiev, Ukraine.

Quijano S., Navarro, J., Yepes, M., Berger, R., \& Romeo, M. (2008). La auditoría del sistema humano (ASH) para el análisis del comportamiento humano en las organizaciones. [Human System Audit (HSA) for the analysis of human behavior in organizations]. Papeles del Psicólogo, 29, 92-106.

Rafferty, A. E., \& Griffin, M. A. (2004) Dimensions of transformational leadership: Conceptual and empirical extensions. The Leadership Quarterly, 15, 329-354. http://dx.doi.org/10.1016/j.leaqua.2004.02.009

Rowold, J., \& Heinitz, K. (2007). Transformational and charismatic leadership: Assessing the convergent, divergent and criterion validity of the MLQ and the CKS. The Leadership Quarterly, 18, 121-133. http://dx.doi.org/10.1016/j.leaqua.2007.01.003

Shamir, B., House, R., \& Arthur, M. (1993). The motivational effects of charismatic leadership: A self-concept-based theory. Organization Science, 4, 577-594. http://dx.doi.org/10.1287/ orsc.4.4.577

Seltzer, J., \& Bass, B. M. (1990). Transformational leadership: Beyond initiation and consideration. Journal of Management, 16, 693-703. http://dx.doi.org/10.1177/014920639001600403

Tejeda, M. J, Scandura, T. A., \& Pillai, R. (2001). The MLQ revisited: psychometric properties and recommendations. The 
Leadership Quarterly, 12, 31-52. http://dx.doi.org/10.1016/ S1048-9843(01)00063-7

Tepper, B. J., \& Percy, P. M. (1994). Structural validity of the Multifactor Leadership Questionnaire. Educational and Psychological Measurement, 54, 734-744. http://dx.doi.org/10. 1021/c160044a010

Tracey, J. B., \& Hinkin, T. R. (1998). Transformational leadership or effective managerial practices? Group \& Organization Management, 23, 220-236. http://dx.doi.org/10.1177/1059 601198233002
Yammarino, F. J., Spangler, W. D., \& Bass, B. M. (1993). Transformational leadership and performance: A longitudinal investigation. The Leadership Quarterly, 4, 81-102.

Yukl, G. (1998). Leadership in organizations (4 ${ }^{\text {th }}$ ed.). Upper Saddle River, NJ: Prentice-Hall

Received March 8, 2010

Revision received February 24, 2011

Accepted March 21, 2011 


\section{APPENDIX}

\section{Items and their theoretical distribution to theoretical subdimensions}

1. Desarrolla formas de motivarnos (He/she develops ways of motivating us) Motivational inspiration

2. Me siento orgullosa de trabajar con él (I feel proud to work with him/her) Charism

3. Confío en su capacidad para superar cualquier obstáculo (I have trust in his/her ability to overcome any obstacle) Charism

4. Se preocupa de formar a aquellos que lo necesitan (He/She is concerned with training those who need it) Individualized consideration

5. Da consejos a quienes lo necesitan (He/She gives advice to those who need it) Individualized consideration

6. Hace que nos basemos en el razonamiento para resolver problemas (He/she gets us to rely on reasoning and evidence to solve problems) Intellectual stimulation

7. Fomenta el uso de la inteligencia para superar obstáculos (He/she promotes the use of intelligence to overcome obstacles) Intellectual stimulation

8. Presenta las cosas con un enfoque que me estimula (He/She presents things through an approach that stimulates me) Motivational inspiration 